\title{
The Status of Married Couples "The Nile River State - Sudan"
}

\author{
Dr. Gobara Alimam Gobara Mustafa
}

Aljouf University - (KSA)

\begin{abstract}
Tracing Prophet Mohammed's (peace be upon him) treatment with his wives visa-vis would find it striking to our minds. If truly one is keen he would follow suit the master of creation. As our prophet Mohammed (peace be upon him) is a school where we can learn from him everything in all matters, in times of earnest, play, pleasure, anger, forbidden and travel among others. Tracing the long life of women in jahiliya (i.e. pre -Islamic era) would find that women were unprivileged and not given due attention and care. Theywere degraded and disrespected. Community would consider women as sex objects. Man did not give them their own rights. Islam is a turning point to women where she was transferred from Jahiliya (pre-Islamic era) to the dawn of Islamic freedom. Women, inJahiliya, would avoid mentioning the real name of a woman. Rather she was called "sheep" As Islam respected women and illuminated their path of life and transcended them from backwardness, one can notice that recently the former status of women shows up as it is evident in daily practices that men rarely go together with their wives. Neither men nor women mention the name of one another as this degrades their status in society. We can see that the Man, or the husband, would call or name his wife by the sons' names as saying "sons left", "sons" came. I went with the kids even though the wife has no sons. These are true instances of man's restraining his wife to fruitless customs and traditions. If one looks into the treatment of couples in our Islamic society would come up with inherited habits and customs far away from Islam. Marriage is a sacred bond if all values and the optimal treatment stem from the holy shrines. Marriage life would undoubtedly become boring which transfers joy and happiness to replace it with hardship and sadness which in turn would affect children's life. Thus, we would have lost the essence of marriage as it is intimate, merciful and secure as stated in the holy Koran "And among His Signs is this, that He created for you wives from among yourselves, that you may find repose in them, and He has put between you affection and mercy. Verily, in that are indeed signs for a people who reflect ". (1)
\end{abstract}

Keywords: married couples

\section{Limitations of the Study}

This study focuses on the status of married couples -Nile Valley State- a case study. The optional treatment of the bright and striking example of our prophet Mohammed's (peace be upon him) home.

\section{Statement of the Problem}

Statement of the problem is represented in the following research questions:

1) Do inherited habits and customs in the Sudanese community have a major role in creating many of family problems?

2) Can men mention the names of the women in the community incontrast; can women mention the names of their husbands among each other?

3) Can couples walk together with one another side by side?

4) Can couples announce their love to oneanother?

\section{Objectives of the Study}

The study aims to

1) Follow suit the Sunnah and traditions of prophet Mohammed-peace be upon him-in his good treatment with his wives.

2) Detcet prophet's wives treatment with the prophet.

3) Knowing the prophet's treatment as well as his wives treatment to follow suit.

4) Detec how couples treat one another in the Nile Valley State.

5) Shed light on couples treatment of one another in urban and countryside societies
6) Detect the extent of customs and traditions amongst couples connected to the Islamic doctrine.

7) Input a detailed data about marriage life at home.

Significance of the study

The study is significant in unveiling the truth and facts in

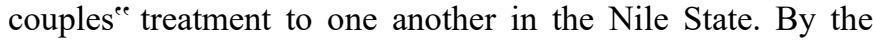
same token, it is significant in how far or close to the Sunnah and traditions guidelines of ProphetMohammed (peace be upon him).

\section{Methodology of Research}

The study adopts an analytical descriptive approach.

Hypotheses of the study

1) Educated wives are well-treated than uneducated counterpart.

2) Kinship amongst couples may prove to be an optimal thing more than amongst alien ones.

3) Women in countryside are controlled by customs and traditions that forbid them from fulfilling the sexual needs of their husbands contrary to urban women.

4) Employed women are better than housewives in dealing with their husbands.

5) As men grow older they become disrespected.

Corpus of thestudy

The corpus of the study is comprised of married couples in Nile Valley State. 
International Journal of Science and Research (IJSR)

ISSN (Online): 2319-7064

Index Copernicus Value (2013): 6.14 | Impact Factor (2014): 5.611

\section{Sample of the study}

Random sample of an equal size(200 males vs.200 females) of married couples is drawn.

\section{Theoretical Framework}

\section{Aspects of the prophet's treatment with his wives:}

The Prophet Muhammad (Peace and blessings be upon him) gave us a striking example of how to treat women in his Sunnah, but so many men follow the Sunnah and forget that a major component of it is the prophets (pbuh) treatment of his wives, this is a reminder for all those guys who are married or inshallahwhen they get married to remember the Sunnah of the prophet (pbuh) and the value and blessing of a wife.

\section{Kidding with them:}

Prophet Mohammed -peace be upon him- was very kind with his wives as he brings joy and happiness. Aisha- may Allah be pleased with her-narrated as saying" I brought the prophet khazira (i.e. pudding) I had already cooked. I invited Sawda as the prophet was between us to eat but she refused.Then Aisha told Sawda" you have to eat or I would stain your face with khazira (i.e.pudding) but she refused. Then I put my hand into the pudding dish and stained her face. The prophet laughed and put his hand and told Sawda to stain Aisha's face. The prophet laughed. Omar bin Alkhattab passed by and called Abdullah,oh slave of God. The prophet thought that Omar would come in and he asked his wives to wash their faces. Aisha narrated that she felt frightened of Omar for the dignity and respect of the prophet-peace be upon him- to Omar. (2)

\section{Sporting and playing with them}

Aisha narrated that she raced with the prophet and she beat him. Then they rested for a while as I was fat. They raced again and finally the prophet beat her as saying "tit for tat" (3)

\section{Adorning Them}

Aisha -may Allah be pleased with her-narrated that the prophet (peace be upon him) said " oh, Ayesh" this is Jebril says "hello" to you. (4)

\section{Eating with them}

Aisha -may Allah be pleased with her- was asked "can a woman eat with her husband while in menstruation period?" She said "yes," I was eating from the piece of meat and giving it to the prophet-peace be upon him-and the prophet puts his mouth in the same place of mine. Moreover, Aisha also narrated that when I drink water from the pot in her menstruation period and give it to the prophet-peace be upon him-he drinks from the same place which touched my mouth.(5)

\section{Praising and thanking them}

The prophet -peace be upon him-said "the rank of Aisha to other women is like the rank of porridge to other food."(6)

\section{Consoling and wiping their tears}

Safiya-may Allah be pleased with her-was travelling with the prophet-peace be upon him- and was her turn to travel him. She was walking slowly. The prophet received her while she was crying and saying "you gave me a slow camel. Seeing that, the prophet wiped her tears with his hands and consoled her.(7)

\section{Helping them in household duties}

Alaswad bin Yazidnarrated that Aisha-may Allah be pleased with her- was asked about the manners of the prophet in his home. Shereplied, he washes his clothes, milks the ewe, and serves himself and when he hears the call to prayers he goes out. (8)

\section{Refraining from beating and abusing them}

The Prophet-peace be upon him- has not ever beaten any woman, any servant or anything in his hand other than fighting in the way of Allah Almighty. He does not avenge anyone harmed him except when preaching the orders of Allah Almighty, at which he takes revenge. (9)

\section{Pleasing his wives}

The prophet-peace be upon him-told Aisha "I know well when you are pleased or angry with me. Aisha asked, "how do you know that?" He said when you are pleased you swear by saying "by the God of Mohammed". But when you are you angry you swear by saying "by the God of Ibrahim". Shesaid "you ree right". I desert your name. (10)

\section{Cordiality with his wives}

Ali bin Hussain narrated that Safiya the prophet's wife told him that she visited the prophet in the last ten days of Ramadan in the mosque. She began rolling and turning. The prophet went with her till they dropped by Um Salameh. The prophet's wife. Two of Medinan followers of Mohammed passed by and greeted him. Then the prophet called them to hold on. They praised Allah. The prophet told them that the Satan is closer to Man than blood is. "I am afraid that suspect would creep into your souls and hearts. (11)

\section{Helping themridingtheir camels}

Anas bin Malik -may Allah be pleased with him-narrated that the prophet came to khaiber. When Allah (swt) made it possible for him to capture the castle, the charm and the beauty of Safiayahbint Huyayi bin Akhtab whose husband was killed while she was a newlywed. The prophet wanted her for himself. Then he accompanied her till they arrived Alrawha dam and married her. He slaughtered a sheep to be cooked. He invited his companions and it was the feast of the prophet.Ater that they went to Madina.Then I saw the prophet used his cloak to hide me. He sat down beside his camel putting his knee andSafiya climbed his knee to ride her camel. (12)

\section{- Demonstrating his love and loyalty to them}

Omar bin Alas narrated oh, messenger of Allah"who is dearest of mankind to you?" Hesaid, "Aisha." andamongstmen, theprophetreplied, her father." (13)

\section{Sewing hisown thobe}

Abdoh told us that Hisham bin Orwah was told by a man asked Aisha" what does the prophet do at home? "Aisha narrated as saying the prophet fixes his thobe and his shoes as well or the like."(14)

\section{Volume 5 Issue 2, February 2016}




\section{International Journal of Science and Research (IJSR) \\ ISSN (Online): 2319-7064 \\ Index Copernicus Value (2013): 6.14 | Impact Factor (2014): 5.611}

Leaning andsleeping in their laps

Aisha- may Allah be pleased with her-said that the prophet peace be upon him-was leaning in my lap while in menstruation period and reciting the holy Quran. (15)

\section{Complaining to themwhen he is sick}

Yehya bin saeed narrated that Alqasim bin Mohammed that Aisha narrated oh;headache.The messenger of Allah said "if it happened while I am alive I would pray for you. "Aisha said "what a pity, oh I swear in Allah that I think you would love me to pass away, even be it you would remain enjoying the company of your wives. Then the prophet cried I had a headache then. I intended to call for Abu Bakir and his son. Then I felt frightened that slanderers would feel happy if I die. Then I said Allah forbid and the believers would not, or Allah would ordeal and the believerswould not. (16)

\section{Forgive themwhen they misbehave}

Anas narrated that the prophet was some of his wives. Then one of them sent him a dish of food. The host of the prophet (i.e. the one whom the prophet is in her house) beat the servant hand and the plate fell down and broke. The prophet gathered the broken shares of the plate and started collecting the food and said "your mother felt jealousy." Then he kept the servant waiting till he was served by another dish and ordered to be sent to the one who has sent it and left the broken shares of the dish at the house where the dish had been broken. (17).

\section{Fulfilling their demands}

Aisha -may Allah be pleased with her narrated that " she went to perform Ummrah(i.e. the lesser piligrimage) but she did not make Tawaf(i.e. moving in acircle round Ka'abahthe black stone) till she had her monthly period. Then on the day of "nafrah"(i.e. leaving from Arafat toMizdalefah). The prophet told her "yourTawaf is enough for your Ummrah and Hajj but she refused. Then the prophet sent her to Atenim (i.e. Migat place where pilgrims get ready to perform either Hajj or Ummrah) withAbdelrahman her brother. Then she performed Ummrah after Hajj. (18)

\section{Honoring hisWives}

Aisha narrated that HalabintKhuwailed Khadija's sisterasked for the prophet's permission. He recognized that and became amazed for that. Hesaid "oh, Hala. Then Aisha said"I felt jealousy". Then I said " what do you remember of old women of Quraish a red-lipped who passed away long time ago. Allah (swt) has substituted you for a better one. (19)

\section{Refrain from beating or abusing them}

Hakim bin MoawiahAlqushairi narrated from his father as saying I asked the messenger of Allah"what is the right of one's own wife?" The prophet replied"he has to feed her, buy her clothes and not to beat her or desert her but at home. Abu Dawoudsaid "never say to her "Allah damn you". (20).

\section{Commentingon Their Ornament}

Aisha narrated that the prophet got angry from SafiyabintHuyey for one thing. Safiya asked Aisha if she would make the prophet pleased with her and you had my night with him. Aisha said "yes", she took a veil dyed with saffron then sprayed water so that it would smell nice. Then she sat down beside the prophet. He said, "oh, Ayesh it is not your night. "She replied it is God's bless bestowed on whoever wishes. Then Aisha told him the whole story. Eventually he became very pleased with Safiya."(21)

\section{Entertaining hiswives}

Aisha used toput herhead onhis arm while she was hiding behind him looking into Abyssinians playing with their spears inside the mosque. Aisha narrated it was a day of Eid.The Abyssinians were playing in their spears. Either Aisha asked the prophet or he asked "would you like to see? „Thenshesaid"yes".Then the prophet and Aisha stood together leaning their cheeks to one another. He invited baniArgdah to look and seetill I got bored or tired. The prophet asked me "is it enough"? I answered yes, .then he told me to go. (22)

\section{Obeying Their Orders}

When the prophet finished of the book affair,he told his companions to slaughter their sheep and have their hair cut. Hesaid"no one had done it till he repeated it thrice. When there was no response, he went to Um Salamah and told her the story. Then she said, "You better go out and do not talk to any one until you slaughter sheep and have your hair cut". Then he left and did all of this. When his friends saw this they did the same till they were about to quarrel. (23)

\section{Honoring their families}

Aisha narrated that HalabintKhuwailed Khadija ${ }^{e e}$ s sisterasked for the prophet's permission. Then he recognized Khadija's permission and he was frightened for that. Then he said, oh Hala. Aisha felt jealousy. Aisha said "what do you rememberof old women of Quraish a red-lipped who passed away long time ago?"(24)

\section{Respecting their friends}

The prophet considers Aisha's young age and her need to play. He used to bring and invite her friends to play with her. Hisham bin Urwah narrated from his father that Aisha was playing with girls at the presence of the prophet. Aisha narrated that her friends Hisham bin Urwah narrated from his father that Aisha was playing with the girls in the presence of the prophet. Aisha narrated that her friends came to her. They used to hide and feel shy of the prophet. Then Aisha said" the prophet was bringing and inviting them to me". (25)

\section{Narratingand Telling Aneckdotes}

Aisha narrated that the prophet used to spend some time with me at night. That is documented in Sunnah books. Aisha narrated that eleven women sat down and promised to disclose the secrets of their husbands. The first one said "my husband is like a sticky camel's meat on top of a mountain. $\mathrm{He}$ is obstinate. The secondsaid "I cannot reveal his secret or news. I am afraid I would not keep any of his traits if I mention him I would mention his weakness. The third one said "if I disclose his secrets I am afraid I would be divorced and if keep silent I would be in between neither married, nor divorced. The fourth one said" my husband is very hard with me as Tehama"snight. It is neither hot nor cold. Besides, there is no worry or boredom". The fifth one said describing her husband as "panther when he comes in and he is a lion when he goes out. He never asks about what he sees." The sixth one said"if her husband eats he folds the bite and if he drinks, he sips. If he lies down he rolls himself .He would not close the palm of his hand to now everything. "The seventh one said 


\section{International Journal of Science and Research (IJSR) \\ ISSN (Online): 2319-7064 \\ Index Copernicus Value (2013): 6.14 | Impact Factor (2014): 5.611}

"my husband is ghayaya. Each illness has a cure." The eighth one said "my husband when he touches her he is like a rabbit". The ninth one said "my husband is generous." The tenth one said "her husband is neither wealthy nor poor. He has a lot of sheep used to stay around and whenever they heard the sharpening of knives, they realize they would be slaughtered". The eleventh one said"her husband is a semi father. He met a woman who has two sons as panther or sheetah playing by two pomegranates. He divorced his wife and got married to this woman. Then I married a man secretly who gave me every wealth and luxury of life ". Aisha said "the messenger of Allah said "I am to you is like Abu Zari to Um Zari."(26)

\section{Preach and advise his wives}

Aisha narrated that I said to the prophet-peace be upon him" forget aboutes this and that". He said "you mean short". Then the prophet said "if I utter a word melted by sea water it would melt. "Then Aisha said and talked to him you human and I have this and that." (27)

\section{Sweep the house}

He weaned when he comes. He said Anas narrated that the prophet was the best ever well- mannered of mankind-. I had a brother called Abu Omar. Then I thought him weaned when he comes in. He said "oh, Abu Omar "what did the boy do? "He was playing. Then he attended prayers at home. Then the prophet asked that the mattress be cleaned." Then the prophets stood and we lined behind him and prayed together." (28)

\section{Drinking from the same place of his wives}

Aisha -may Allah be pleased with her- asked "can a woman eat with her husband while in menstruation. She said, "Yes", the prophet (messenger of Allah) used to invite them while in menstruation. He used to take the rib of cooked meat and we eat it in turn. Then, the prophet ordered for water and swore that I would sip or drink first and then he took it and drank from the same place of mine“(29)

\section{Aspects of Prophet Mohammed's Wives Treatment with him:}

\section{1- Praising Him}

Aisha - may Allah be pleased with her- loved the prophet so much and was jealous for him. This is evident in narrating the following incident. "Once the prophet went out of her home at night, she said" I felt jealousy. „Then the prophet came and saw what I did. Then he asked what about Aisha? Did you feel jealousy? Then Aisha replied why should not I? Then the prophet told her were you seduced by the Satan. Then she asked did I have one? The prophet replied yes, with every human there is one. Aisha asked him did you have one. The prophet replied Allah (swt) helped me in this affair till the Satan embraced Islam. (30)

\section{2- Relieving his worries}

The prophet-peace be upon him-came back from Hira'a cave shivering and his heartbeat. He entered into Khadija's roommay Allah be pleased with her-and asked her to cover him as saying "zamlunizamiluni".(i.e. cover me". Then she covered him until he felt comfortable. The prophet told Khadija the whole story as saying 'I was frightened and panicked". She said, No, No. Allah (swt) would never disappoint you as you have strong kinship ties and bears every one and gain and support the poor, honor the guests, aid and assist to overcome the calamity. (31)

\section{3- Consoling Him}

IbnHisham narrated that Khadija was the first believer of Allah and his prophet Mohammed. She believed in everything he said and did. This helped and lessened his worry. The prophet felt sad when people did not believe in what he said to them. Khadija was the prophet's relief as she used to back support and believe in him to make it easy for him to deal with people. (32)

\section{4- Tolerating poverty life}

Aisha narrated that when the prophet -peace be upon himpassed away there is nothing to be eaten except a shelved barely sack. Then I ate it all. (33). YehyaibnSa'ad narrated as saying he heard Alqassim bin Mohammed narrated that Aisha may Allah be pleased with her-had a headache. Then the prophet said "If I were a live I would pray for you. Then Aisha said oh, God. I think you would my death. If it were the case, you would remain staying with some of your wives. Then the prophet-peace be upon him-cried "I had a headache. I intended to call Abu Bakir and his son. I assume that the slanders would say or wish what they would like. Then I said Allah would forbid and the believers would push a way or the believers would not. (34)

\section{5-Kidding with the prophet}

SawdabintZim'ahwas well known for her fun and entertainment when talking to the prophet. Ibrahim narrated that Sawda told the prophet as saying "I prayed behind you yesterday. Then you bowed until you grabbed my nose so that it would not bleed. The he narrated the prophet laughed and she used to amuse him with the same thing. (35)

\section{6- Combing his hair}

Hisham bin Urwah narrated from his father as saying that Aisha narrated I was combing the prophet's hair when I am in menstruation period." (36)

\section{7- Not sleeping Angry}

Omar bin Alkhattab told the prophet - peace be upon him-" you witnessed oh prophet while we folk of Quraish beat the women. Then we arrived in Madina we found women beat the men. Then our women rushed to learn from theirs. Then Omar narrated he got angry with his wife and then she talked to me about it. I denied it. Then she said "what did you deny?" Oh, God the prophet's wives would reconcile with him. One of them deserted the prophet till night. Then Omar bin Alkhattab asked Hafsah" Have you reconciled with the prophet? She replied "yes". One of us deserted him till night. Omar said who did this amongst you with the prophet, he would lose. Would you be safe from the wrath and fear of Allah (swt) for the sake of the prophet's anger? (37)

\section{8-Cleaning his Thobes}

Janabah touches the thobe. Aisha narrated that she used to clean the thobes of the prophet-peace be upon him-then he goes out with spots of water is clearly seen. (38). 


\section{International Journal of Science and Research (IJSR) \\ ISSN (Online): 2319-7064}

Index Copernicus Value (2013): 6.14 | Impact Factor (2014): 5.611

\section{9- Listening to their advice}

Aisha -may Allah be pleased with her-narrated as saying the Jew used to greet the prophet as saying "asamaleikum" meaning "damn you"? Then Aisha remembered their greeting as saying" aleikumasamwalla'anah"(i.e. god damn you).Then the prophet - peace be upon him- told Aisha "hold on". Allah would love us to be kind." Aisha said " oh, prophet have you not heard what they said. He said "have you not heard what I answered back as saying "waaleikum" which means "God damn you." (39)

\section{0-Offering Money to the Prophet}

Aisha narrated as saying when the prophet mentioned and praised Khadija. He asked her she felt jealousy". Aisha answered as saying you frequently mentioned her red mouth lip. Allah (swt) substituted you for a better one. Then the prophet said Allah (swt) would not substitute me with a better one. She believed in me while people did not . She offered me her money while people deprived me .More than that Allah (swt) bestowed me with her sons and daughters where I was deprived of sons and daughters from others. (40)

\section{Practical Study}

SPSS was adopted to analyze data and came up with the following findings:

First, in general, the percentage of applying and following suit the guidance and Sunnah traditions of the prophet Mohammed-peace be upon him- as shown in the following table.

Table 1:

Applying the Guidance

The Sunnah of the prophet Male Percentage Female Percentage

\begin{tabular}{|c|c|c|}
\hline Always & $58 \%$ & $68 \%$ \\
\hline Rarely & $25 \%$ & $23 \%$ \\
\hline Never & $17 \%$ & $9 \%$ \\
\hline
\end{tabular}

Source: The Researcher

As shown above, it is obvious that women scored $(68 \%)$ higher than their male counterpart who scored (58\%) as regards following suit and applying the Sunnah of the prophet in the relationship among couples.

As the percentages are weak in comparison with the significance of the study of the research is under investigation. That is to say (42\%) for males and (32\%) for females who do not follow suit the Sunnah traditions and guidance of prophet Mohammed-peace be upon him-.

Second, Analysis was carried out to detect whether the subjects' responses were affected by variables of: education level, age, kinship amongst couples, job and place of residence whether it is urban or rural. It turns out that the subjects' responses, in general, were independent and not related to the above mentioned variables where the mean score when using Kie Square Test was more than (0.05).

Third, there are special cases for some Sunnah traditions or guidance of the prophet to be adopted in which the majority of the subjects of the study do not follow suit or apply. These are as follows:

1) When women did not comb their husbands' hair or take care of their look before going out or staying with their wives.

2) When men do not please and wipe their wives tears when they cry. More than that, men do not recite the holy Quran in their wives laps when they are in menstruation period, or helping them riding their camels etc.

Fourth, there are certain special cases for some Sunnah traditions or guidance of prophet Mohammed-peace be upon him-which revealed the lack of independence with some characteristics or features. These are as follows:

1-When women have to relieve the worries of their husbands and listen to their advice. This shows lack of independence with the level of Education .Post graduate degree holders take care of their husband ${ }^{\text {ee }} \mathrm{s}$ outlook and physical appearance before they go out proved to be not related to age. The findings opted for young couples. That is to say, the woman has to love and do what her husband loves and does. This showed lack of independence with kins for the sake of couples who do not have kinship bond. As for giving their money willingly to their husbands as well as loving what their husbands love showed to be dependent with the job. The results opted for the employed women.

As regards men eating with their wives, it showed lack of independence with education level. The results opted for the time couples spent together. To answer frankly, where have you been? This proved to be independent with age. It turns out to be for the sake of old couples, as regards kidding and entertainment, joining them in travel.

Entertaining and joining women in travel and eating with them proved to be lack of independence with residence. The whole thing opted for city dwellers.

\section{Conclusion}

The research paper under study came up with the following findings:

1) Women follow suit of the Sunnah traditions of marriage life more than men.

2) Formal treatment away from sympathy and feelings governed by habits and customs is most prevalent among couples.

3) The percentage of applying and following suit of the Sunnah traditions among couples is higher than older couples. However, as regards Sunnah traditions related to formal treatment it is higher among elderly ones.

4) 4-As regards applying the Sunnah traditions related to making love. City dwellers scored higher than countryside couples. Similarly, this applicable to educated and uneducated couples, employed and un employed women amongst alien couples who have no kinship ties respectively.

\section{Recommendations}

1) Couples should be well aware as regards marriage life of the prophet's Sunnah traditions and guidance. Many couples are ignorant in so many things the do/do not are 


\section{International Journal of Science and Research (IJSR) \\ ISSN (Online): 2319-7064}

Index Copernicus Value (2013): 6.14 | Impact Factor (2014): 5.611

basically of our prophet's Sunnah so that we can follow suit.

2) Awareness of the prophet's Sunnah as regards marriage life should focus on couples dwellers of the countryside. The majority of uneducated, kinship marriages and un employed women who lack applying and following suit Notes of the Sunnah traditions centers in countryside.

1- Ar-Rum Surat verse (30)

2-Musnad AbiYa'li - 7/499 - Hussein Salim verification

Al Ma'moun for heritage publishing House.-Damascus

First Edition.

3-Sahih ibnHayanShuaib Al arnaut verification

Arisalah Publishing Institution- Beirut.

4- SahihAlbukhari - Kitabalmathaqib - Aisha's Rank chapter

Touq house for Publication

5- SunanAnnisai - second edition verified by Abdel Fattah

Abu Gheda.

Islamic printing Library-Aleppo

6- Sahih Al bukharikitabAshabAnnabi Aisha's Rank chapter

7-Musnad Al Imam Ahmed -shuaibalarnaouf verification-

Arisalah Publishing House.

8-Sahih albukhari- annafaqat- expenditure-chapter -man serving his family.

9-musnad Al imam Ahmed

10-Sahih Al bukhari -nikah book- jealousy of women chapter sales book

11-ibid- fardalkhams- the prophet's wives homes

12-ibid-Albeu' sales book can he travel with maids

13-ibid- Almaghazi book- ghzwat that asalasil

14- musnad Al imam Ahmed

15-sahih Al bukhari- Alheyd book-menstruation bookreciting the holy Quran in their laps.

16-sahih albukhari -kitabalmathagib -babalistikhlaf

17-sahih albukhari-nikah book- jealousy chapter

18-sahih Muslim - Al ihram chapter-Arab heritage Revival publishing House-Beirut

19-sahih al -bukhari- the ansari traits book- zawaj chapterMarriage Chapter.

20-sunan Abidawood - the woman's Rights to her husband verified by Mohammed MoheyiEdin -Modern library publishing house-Beirut.

21-sunnan IbnMajah- A woman offering her night to her friend chapter- verified by Mohammed Fuad Abdel Bagi.

22-sahih al- bukhari- Friday book-swords shields and soears chapter-Eid day.

23-sahih ibnHayan-whait is favored by Imam-arisalah Publishing House.

24- ibid

25-sahih muslim- Fadailasahabah book- the rank of Aisha.

26-sahih al bukhari-Al manaqib book-well -treatment of women chapter.

27-sunnan AbiDawood- kitabbabalgheirah- jealousy chapter

28-sahih albukhari-kitabaladab nickname chapter.

29- ibid

30-sahih muslim-doom's day heaven or fire

31 sahih albukhari- the beginning of Jebril's revelation to the prophet chapter.

32-sirat ibnhisham -Badr Battle chapter.

33-sahih al bukhari-five prayers book

34- ibid 35-atabagat alkhubra-um almu'mineen-sawdahbintzim'ahscientific book publishing house-Beirut

36-sahih al bukhari-alhayed book-alhai'dh washing her husband head.

37-sunnan atirmithi-Atahrimsurat- verified by Ahmed Mohammed Shakir

Mustafa Albagi Al halabi bookshop

38-sahih al bukhari -Alwudu- Ablution -janabah chapter bath

39-sahih al bukhariadawat book

40-musanad Al Imam Ahmed

\section{References}

[1] IbnQutaibeh: ashirwaashura Poets \&poetry Dar Al hadith publishing house Cairo $1422 \mathrm{H}$.

[2] Alquraishi, Abu Zaid: jamhratasha'ralarab -Anthology of Arab poems MisrNahdah printing press.

[3] Abu ya'aliMusnad -verified by Hussainsalim-first ed. $1404 \mathrm{H}$

[4] Sahih binhayan -verified by shuaib Al Arnaouf -first ed.Arisalah establishment publishing house- Beirut

[5] Sahih al bukhari-Dar Tawq publishing house first ed.

[6] Sunnan Annisai -verified by Abu ghedahAbdelfattahIslamic print Bookshop second ed. Alleppo.

[7] Al imam Ahmed Musnad- verified by ShuaibAlarnaout Arisalah Publishing House, first ed.

[8] Sahih Muslim Arab heritage revival publishing houseModern Bookshop, Sideon, Beirut

[9] SunanAbidawood- verified by Moheyedin, Mohammed Modern bookshop Library, Beiirut

[10] SunnanIbnMajah- verified by abdelbagi Mohammed fuad Revival of Arab Book Publishing House

[11] SahihibnHayanAlrisalah establishment ,first ed. 1408

[12] Attabagat Alkubra Scientific Book Publishing House first ed.

[13] sunnanAtirmithi verified by shakir Ahmed Mohammed ,First ed.

[14]Al Hilai ,T.\&Khan,M.:The Noble Quran Translation King fahd Complex for the Printing of the Holy Quran Madinah K.S.A. 